Mercator, Fortaleza, v. 17, e17007, 2018.

DOI: https://doi.org/10.4215/rm2018.e17007

ISSN: $1984-2201$

Copyright @ 2002, Universidade Federal do Ceará

\title{
NARRATIVES OF NORTHERN SERTÕES URBANIZATION
}

\author{
ARRAES, Esdras a*
}

(a) Phd in Sciences. University of São Paulo (USP). ORCID ID: https://orcid.org/0000-0003-0374-7401. CURRICULUM LATTES: http:// lattes.cnpq.br/0462029779554770

\section{(*) CORRESPONDING AUTHOR}

Address: USP - Rua Prof. Luciano Gualberto, 315, Sala 1007, CEP: 05508080, São Paulo (SP), Brasil. Tel: (+55 11) 30913761

E-mail:esdrasarraes@gmail.com

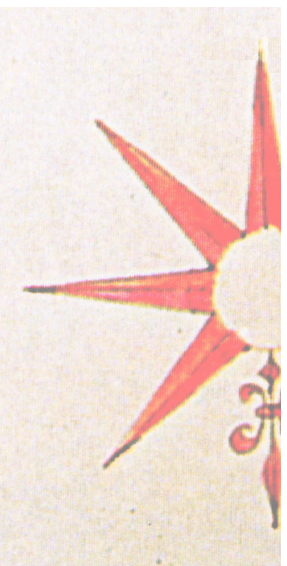

\begin{abstract}
The scant cartographic information on the processes of occupation and transformation of the sertões of the captaincies (royal land grants) of the North presents challenges to the researchers. On the other hand, the abundant documentation written by Royal officers (civil and ecclesiastical) shows the sertão hidden in images, structured by a hierarchical network of settlements formed by towns, villages, parishes, julgados (legal/administrative areas) and filial chapels. This essay intends to represent the sertões outside of the "cartographic scene" created in the seventeenth and eighteenth centuries, showing dynamic territories transformed into landscapes. Political and cultural relations will be treated as foundational to the formation of macro-landscapes shaped in space over the long term. The methodology interweaves text (hermeneutics) and image (representation) to think with the urbanization processes emanated by the Portuguese Crown or those operating in the inhabitants' daily life. Georeferencing was also used, in order to place the settlements in the territory and interpret the reason for their geographical position in the social-political context in which they were inserted.
\end{abstract}

Keywords: Cartography; Landscape; Representation; Sertões of the North; Urbanization.

\section{RESUMO / RESUMEN}

\section{NARRATIVAS DA URBANIZAÇÃO DOS SERTÕES DO NORTE}

As poucas informações cartográficas que objetificam os processos de ocupação e transformação os sertões das capitanias do Norte introduziram desafios aos pesquisadores. Em contrapartida, a farta documentação escrita por oficiais régios (civis e eclesiásticos) representa os sertões ocultos nas imagens, estruturados por uma hierárquica rede de povoações formada por cidades, vilas, julgados, freguesias e capelas filiais. Esse ensaio apresenta um esforço de representar os sertões fora da "cena cartográfica" desenhada nos séculos XVII e XVIII, dando a ver territórios dinâmicos e transformados em paisagens. Relações políticas e culturais serão tratadas como basilares à formação de macropaisagens conformadas no espaço em longa duração. Como metodologia, entrecruza-se texto (hermenêutica) e imagem (representação) para pensar os processos de urbanização emanados da Coroa portuguesa ou daqueles operados no cotidiano dos habitantes. Vale-se de programas de georeferenciamento a fim de localizar as povoações no território e interpretar as razões de sua posição geográfica no contexto sociopolítico ao qual estavam inseridas.

Palavras-chave: Cartografia; Paisagem; Representação; Sertões do Norte; Urbanização.

\section{NARRATIVAS DE LA URBANIZACIÓN DE LOS SERTÕES DEL NORTE}

Las pocas informaciones cartográficas que objetifican los procesos de ocupación y transformación de los sertões del Norte han introducido desafios a los investigadores. Por otro lado, la documentación manuscrita representa los sertões ocultos en las imágenes, estos estructurados por una jierárquica red de poblaciones formada por ciudades, villas, julgados (juzgados), parroquias and capillas. Este artículo es un esfuerzo de representar esos sertões que están fuera del "escenario cartográfico" dibujado en los siglos XVII y XVIII, exponiendo territorios dinámicos y convertidos en paisajes. Relaciones políticas y culturales serán tractadas como fundamentales a la formación de los paisajes construídos en longa duración. Como metodologia se entrelaza texto (hermenêutica) e imagen (representación) para pensar c los procesos de urbanización emandos desde la Corona portuguesa o daquellos operados en el cotidiano de sus habitantes. Se usa Sistema de Información Geográfica con el objetivo de situar las poblaciones en el território y interpretar las razones de sus posiciones geográficas en el contexto social y político en que estaban incluídas.

Palabras clave: Cartografia; Paisaje; Representación; Sertões del Norte; Urbanización. 


\section{INTRODUCTION}

The theme of this article is to understand some of the territorial and urban transformations that occurred in the sertões ${ }^{1}$ of the captaincies (royal land grants) of the North through the policies of the Portuguese Crown. These transformations, read as urbanization processes, resulted in the progressive construction of a hierarchical network of settlements formed basically by filial chapels, parishes, julgados (legal/administrative areas), villages and towns. Therefore, the understanding of these units as a whole requires the use of at least three analytical scales: a micro one, which deals with the episodes occurring on a village scale; another that can be called "chorographic", which refers to the study of a captaincy, a county or town; and, finally, the macro dimension related to holistic issues, involving the northern sertões of the captaincies of Maranhão, Piauí, Pernambuco and its annexes (Ceará Grande, Rio Grande, Paraíba), Bahia and Sergipe del Rei. The macro-scale translates, so to speak, the ways urbanization policies have "objectified" themselves (MILLER, 2013 , p. 90) in the territory and landscape in official settlements strategically positioned to favor the geopolitical plans of the Crown, its representatives and / or the local elite. The French historian Bernard Lepetit (2001, p. 225) stated that the choice of a particular scale seeks to comprehend the conformation and arrangement of objects in the territory, without, however, contradicting what is perceived in other dimensions. On the contrary, "the conclusions that result from an analysis conducted on a particular scale cannot be opposed to the conclusions obtained on another scale". For Beatrice P. Siqueira Bueno (2016, p. 826), the challenges of the macro-regional perspective are desirable precisely because the research predominating in Brazilian Historical Geography and Historiography is concerned with examining urbanization within watertight areas, whose contours are confused with the territories of present-day Brazilian States.

Few maps indicate the complexity of the network of towns of the northern sertões in their symbols. The majority placed some indigenous ethnic groups in the territory and punctuated by a few filial chapels, parishes and villages. Thus, the "void", the incognito and the uninhabited emerge as the images of the sertões. However, it must be clear that the intention herein is not to "exorcise" unknown information from these maps. Cultural geographer J. Brian Harley (2005) in his essay Silencios y secretos. La agenda oculta de la carografia em los albores de la Europa (Silences and Secrets, Chorography's hidden agenda in the dawn of modern Europe) - showed that the hermeneutics of these mapped narratives were in some ways anchored in the context of the other maps that the cartographers used when drawing their own. That is, and applicable to our own analysis, if the "void" and uninhabited represented the sertões, this was due to the "absence" of maps whose contents represented their urban network. Cartographers "inherited", often by accumulation, the image of the void and from it they (re)introduced the sertões.

On the other hand, the official documents expose "other" sertões substantiated in a rich network of villages and daily practices on different scales. The handwritten textual sources describe the materialities produced by the Portuguese Crown's processes of settlement and urbanization policies. In between the lines of the discourse, the ways in which the territory's inhabitants appropriated it and turned it into landscape are evident. That is to say, how day-to-day operations took on a key role in the conversion of undefined regions in certain places. The following example illustrates this point. Around 1672, there were corrals, farmsteads and chapels from the mouth of the São Francisco river until around 120 leagues inland. In Capuchin Friar Martin de Nantes' first Relação, although the sertões had acquired a sublime image of "vast and frightening solitudes" (MARTINHO DE NANTES, 1975, p. 35), hermitages were situated in the missions of Uracapá and Aramurus, as well as in the village of Pambú, administrated by a chaplain maintained by residents of the region. In addition, the Portuguese and the African slaves traveled to celebrate Holy Days in religious places in the villages, "bringing string instruments and guitars to the solemnity and singing many tunes, and shooting rifles to demonstrate their joy" (MARTINHO DE NANTES, 1975, p. 16).

(1) Translator's note: Vast semi-arid regions in the Northeast of Brazil 
Aspects of the hermeneutics of official texts are also noteworthy. According to the Portuguese historian Amelia Aaron Andrade (2001, p. 54), these documents, although starting from a concrete reality, tend to be marked by the background and objectives of those who produced them, as well as the dominant traits of the social imaginary of the time in which they were written. Nevertheless, questioning their applicability is the only criteria to recognize their efficacy and the accuracy of their promulgation.

Thus, the dialogue between the cartographic image and the written document underpins the methodological-theoretical and empirical approach of this text. The interweaving of these sources allows the production of thematic maps whose goal is to transport the sertões of the North to "other" representations, unlike the norm which gravitates towards the "void", with a network of extremely fragile settlements or as peripheral space to Portuguese interests. Cartography and thematic maps (and to some extent the written sources) stimulate visual readings of the landscapes of the sertões in different geographical dimensions, but also on the objectifications of the urbanization policies issued by the Crown or their representatives. The thematic maps explain, in different ways, the reason for the location of settlements in the territory and the implications for the social fabrics therein. Therefore, they are one of the facets of the "geography of the view", in the happy interpretation of Italian architect Renzo Dubbini (2013, p. 90). Or, in the poetic words of the Argentinian art historian Damián Bayón (1993, p. 18), it is necessary to pensar con los ojos (think [images] with the eyes), within which one can discover and integrate worlds and take on the phenomena of their creation.

\section{NARRATIVES OF THE URBANIZATION AND THE LANDSCAPE OF THE NORTHERN SERTÕES}

Is a difficult, perhaps almost impossible, task to define the geographical limits of the sertões of Northern colonial period, as they are completely unlike the current northeastern sertão known to all and established by recent policies, initiated in the first Republic and consolidated with the foundation of the SUDENE. The sertões had come to exist in the colonial imaginary since the arrival of the armada of Pedro Álvares Cabral, in 1500. These places were not far away from the coast, as is commonly thought, instead they were in the Atlantic Forest, the sertões of the many colorful birds seen by Pero Vaz de Caminha (CASTRO, 2015, p. 106). As colonization progressed, the sertões came to be understood as mostly interior regions. In the dictionary of Raphael Bluteau (1712-1728, v. 7, p. 613) the entry sertão and its cognates - "certam", "sertam", "certão" - were defined as regions away from the sea, between lands. Antonio Moraes Silva's (1813, p. 693) definition of the word differs little from Bluteau's, being understood as the interior, the "heart" of the land. Thus, the lexicon shows the framing of the "certão" in the Mediterranean, between a metaphorical frontier the heart of the lands - and a specific limit - the Atlantic Ocean, for example.

In 1587, the chronicler Gabriel Soares de Sousa narrated the state of the settlement of these regions, their indigenous inhabitants, and detailed some utilitarian aspects of the territories. Writing about the São Francisco River, Sousa mentioned the occupation of its banks, being always "very populated... as the soil is very fertile on the riversides, and there are large catches of fish" (SOUSA, 1971, p. 63). The primitive inhabitants, generically called tapuia, "were so many and they are so divided in groups, customs and languages, that to say much about them would require one to deliberately and slowly find a lot of information on their divisions, lives and customs" (SOUSA, 1971, p. 338). In this scenario, the sertões of the captaincies of the North were not pristine, but they had been changed according to the techniques employed in the indigenous people's way of life. The modifications occurred both in the local ambit - the construction of villages and felling the forest to plant cassava, for example - and in wider measures - the development of trails and large fluvial displacements. 
The Portuguese colonizers were interested in the subtle marks left by the natives on the territory and the cultural contacts operated between them. Without indigenous knowledge the foreign occupation would be difficult or impractical, because the indigenous people were the experts of the sertões. In their paths they demanded people who were hopeful of finding treasures or of capturing Indians to work on the coast. During this deployments, routes were written down and maps were sketched. The mysterious journey of Belchior Dias Moreia, who situated the silver mines in the sertões of Bahia, emerged from this desire to know and explore the territory. Years later, in 1725, Pedro Barboza Leal, still dazzled by the mirage of silver, followed a similar course to that of Moreia under the command of the viceroy of Brazil, Vasco Fernandes César de Menezes (FREIRE, 1977, p. 10).

Neither silver nor gold, but saltpeter. This mineral attracted the governor general, D. João de Alencrastro, to the interiorized zones. He went inland from Cidade da Bahia into the captaincy eager to extract saltpeter, a raw material of gunpowder. At the time, some production workshops were established with indigenous workers, like the Abreus administered by Leonel de Abreu e Lima (AHU_ACL_CU_PERNAMBUCO, Cx. 20, D. 1938). In order to avoid further clashes between the natives and the Crown's agents in the workshops and mines, the governor created the mission of the Sahy, administered by Franciscan friars, with the aim of controlling the Indians by inserting them into the current socioeconomic situation. The design of the workshops had a great house for the tank and boilers to separate the salt; a warehouse to store it once it had been purified, houses for the steward or warehouseman and accommodation for the Indians and slaves, as well as barracks for soldiers in case of an indigenous uprising (PUNTONI, 2002, p. 32). The workshops built in the dusk of the 1600s had little success, thwarting the extractive enterprise, but were advantageous in defining sertões formerly considered unknown.

Years later, saltpeter would return to the arena of the dialogues of the royal authorities. In 1755 , the quartermaster general Wenceslau Pereira da Silva recognized its importance in those years of diplomatic instability between the Iberian kingdoms. With that, the official recommended Manoel Dias Mascarenhas, "a practical man, and versed in the mines, provider of the regulation of gold from the Rio das Contas" (ANTT, mç. 599, paragraph 41), to go to the sertões in order to ascertain the capacity of saltpeter production. A rich written and cartographic documentation describes the processes of obtaining the salt and the recognition of the possible areas of extraction. In the map entitled Serra dos Montes Altos, drafted by the supplier, in addition to locating about 10 mines, it traced routes connecting the coast of Bahia to the sertões of the São Francisco River and a network of farms that articulated the residents with the neighborhood or more distant lands. Mascarenhas wrote an exquisite report relating the landscape and the territory to utilitarian goals. In addition, he distinguished between the workshops extracting saltpeter, locating them precisely on the Salitre creek, helping us to think about the manner of the occupation and formation of the landscape in that part of Bahia. In fact, the first workshop was called Sergento, erected on the land of the sergeant-master João dos Reis Santos; the second was the Abreus mentioned above; then, twelve leagues away from the Abreus workshop, was the Taboleiro (ANTT, m. 599, paragraph 47).

Returning to the geopolitical conjuncture of the late seventeenth century, in 1695, Alencrastro approved the creation of a road that would link the two capitals of the states of Brazil and Maranhão and Grão-Pará (AHU_ACL_CU_MARANHÃO, Cx. 9, D. 906). The Jesuit Jacob Cloceo was commissioned to produce a map and route "for knowledge of the sertão and the land through where the path is discovered (AHU_ACL_CU_MARANHÃO, Cx. 9, D. 906). The route crossed vast areas populated with ranches and farmsteads. Chapels and parishes were built in the vicinity of the road in order to facilitate communication between States, attracting settlers and ascertain the economic potential of the land. In fact, the parish of Nossa Senhora da Vitória (future village of Mocha and town of Oeiras do Piauí), established under royal approval in 1697, guided cotton traders in São Luis for many years. In addition to this parish, the path, later called royal cattle path and way of the cattle herds of Piauí connected different types of settlements along its curves. A traveler would pass through towns (Bahia, Oeiras do Piauí, São Luís), villages (Agua Fria, Jacobina, Vila Nova da 
Rainha), julgados (Itiúba, Aldeias Altas), parishes (Juitani and Santo Antônio), a religious mission (Juazeiro) and passages (Juazeiro and Santo Antônio).

The royal cattle route was one of the most used, mainly by cattle drivers of herds raised in the captaincy of São José do Piauí and in the sertões of Jacobina. Many others were created to boost the social, economic and symbolic exchanges between the sertões and the coast. In 1738, there was the road that linked the village of Recife to the Gerais mines passing by the Ipojuca and São Francisco rivers (IEB/USP-COL.ML, 72.60). Carlos Studart Filho (1937, p. 15-37), a historian from Ceará, narrated the routes and crossways of the roads of Taquara, Camucim-Ibiapaba, the general of the Jaguaribe, nova das Boiadas, das Boiadas, da Caiçara, Crato-Piancó and Crato-Oeiras. In the "General Charter of the Province of Maranhão", drawn up circa 1820, under the coordination of the military engineer Antônio Bernardino Pereira do Lago, it showed the territory of Maranhão crossed by several routes, linking human settlements with each other and with the territory.

Pereira do Lago distinguished two modalities of paths: neighborhood paths related to the settlers' daily lives, who opened them for domestic purposes; and royal paths, that is, public thoroughfares, which were larger, with a variable width and originating from official projects. The public character of the Royal Road arises, in thirteenth century Europe, in the sense that the King "personifies" State protection of the road (OSORIO, 2000, p. 49). Among the royal paths in the captaincy of Maranhão, the engineer cites the das Boiadas, of the village of Guimarães, the Correios, Ouro, Galho and Sertão (LAGO, 1822, p. 16). Other royal or neighborhood routes were opened in all the Northern captaincies, such as the road from the Port of São Félix to the Serra dos Montes Altos that met the imperatives of saltpeter extraction. On a map by the cartographer Henry Antonio Galuzzi, it can be observed that the captaincy of São José do Piauí was connected from North to South by routes expanded beyond the official constituency, symbolizing experiences lived on the scale of the territory.

In that respect, as well as in other ambits, the landscapes of the northern sertão were constructed from the execution of Crown projects and the day-to-day operations of the inhabitants. The first agent transformed the inner zones on various scales, orbiting between the micro and the macro. The landscape constructed by the high-minded decisions of the Kingdom is aligned with what John Brinckerhoff Jackson (1984, p. 150) called the "political landscape", the result of the deliberations of a central power, structured to impose unity or to reform the territory, according to religious, moral and cultural goals. Whereas the one created by the inhabitants of the sertões emerged from the modification of the world according to the practices of daily life, from personal tactics, in the words of Michel de Certeau (2012, p. 44).

The transformations of the sertões also occurred at the urban level when the Portuguese Crown decided to establish villages in nerve centers and strategic points in the territories. The creation of these villages was late when compared with other northern captaincies, specifically in the areas where sugar cane and tobacco were cultivated. The delay was, as justified by the Ultramarino Council, due to the dispersion of the population and the inability of the residents to take on official positions. The village of Mocha, created in 1712 and installed in 1718, was one of the pioneers. Jacobina appears in 1721, implanted in area of gold extraction, permitting accurate surveillance on the taxes (quintos) charged. The final years of the second decade of the eighteenth century presented new indexes: in the region of Bahia, in an area bordering Sergipe del Rei, the towns of Itapicuru de Cima and Inhambupe were erected (AHU_ACL_CU_SERGIPE, Cx 3, D. 22). Years later, Inhampube lost the status of village and was attached as a subordinate settlement to the village of Água Fria. Until 1750, in addition to the aforementioned municipalities, those of Vila Nova do Rio São Francisco (1732), Icó (1736), Rio de Contas (1745) and Urubu (1748) were founded (Figure 1).

The choice of settlement to be promoted to village status was not made by chance. It was a complex geopolitical process that considered geographical reasons (distance of the county seats, the location of the parish headquarters and the utilitarian quality of the territory, such as perennial rivers rich in fish, good air and fertile soil), and demographic and economic ones. However, the 


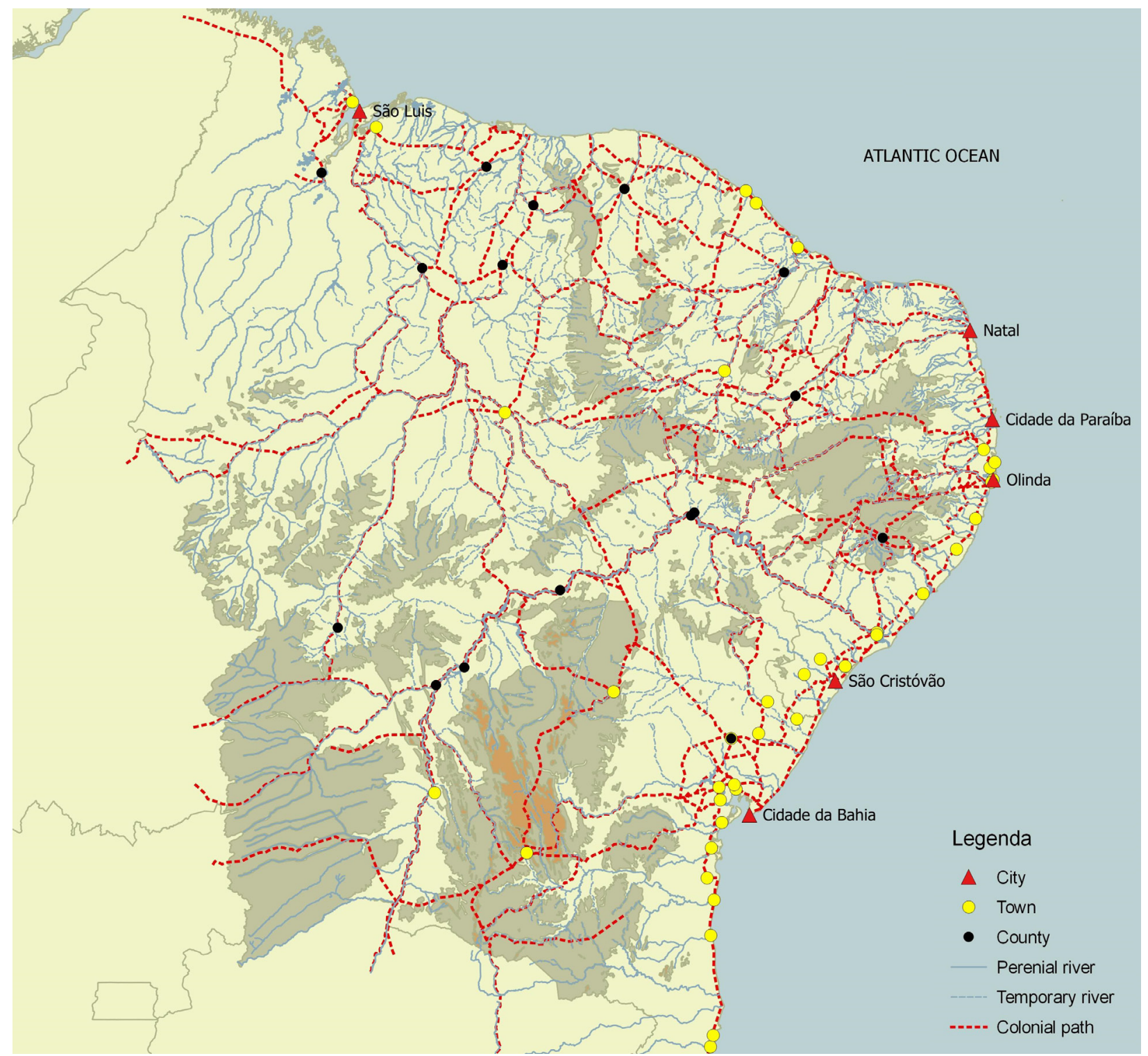

Figure 1 - Network of settlements of the captaincies of the North in 1750. Created by the author through a georeferencing program (Quantum GIS) on cartographic basis of the Brazilian Institute of Geography and Statistics (IBGE). 
"remedy" of injustice (social and landownership) appears as the fundamental motive for establishing the village. In disciplinary action in the villages of Jacobina and Rio de Contas, the general ombudsman and overseer of the region of Bahia, Pedro Gonçalves Cordeiro Pereira, reported to the Crown the usefulness of establishing ...

Another (village) again in the site of Arrayal do Ryo de Sao Francisco, which is half way, and leaves this town for the general mines, where there continue to be many deaths, for lack of justice, preventing in more trade, travelers fear passing through these Sertões that are already distant from this town, more than two hundred and eighty leagues, which would be prevented by creating a village in this place (AHU_ACL_CU_BAHIA, Cx. 22, D. 2024). ${ }^{2}$

The reparations and displacements of the regal authorities through the territory were the appropriate moments for the population to request the creation of a village in their parish or julgado. In most of the cases analyzed, the agents who required the hierarchical promotion included the local elite, desirous of administrative and judicial control of the county, should it achieve official status. In 1724, the Ombudsman of the county of Paraíba, Manoel da Fonseca e Silva, toured the banks of the Piancó, Piranhas, Assú and Apodi rivers. There he found populated sertões subject to the justice of the julgado of Piancó (created by royal order in 1711). He realized that the cattle ranches were articulated in a trade network between the captaincies of Ceará, Rio Grande and Pernambuco. The conditions mentioned above appear in the ombudsman's missives regarding the potential of the settlements pleading for the title of village. With respect to the riverside of the Açú, captaincy of Rio Grande, Fonseca e Silva reported to the Crown:

There is the creek of Assú, of the Captaincy of Rio Grande, as well as the abundant number and settlers, to erect a village, an admirable and pleasant site, to establish what is called Curralinho seven leagues from the parish church. By the sea, where the boats from Pernambuco come, in a wide, deep river with all the provisions necessary for the inhabitants, which is enough to achieve the intentions: it is rich in fish as the sea is one league away and the surrounding land is suitable for producing manioc, which is made in to flour, and abundant in cattle herds, which is all that is necessary to live in these conquered lands (AHU_ACL_CU_PARAÍBA, Cx. 5, d. 428). ${ }^{3}$

In quantitative terms, the number of villages in the northern sertões increased during the ministry of Sebastião José de Carvalho e Melo, the Count of Oeiras and future Marquês de Pombal, whose policy was to define and reorder territories, with the villages as the reason for his architecture. As Renata Araujo pointed out $(2010,190)$, villages and towns, hierarchical levels that convert spaces into the urban and civilized, built the territory in official terms.

The case of the captaincy of São José do Piauí is an example. ${ }^{4}$ The creation of the village of Mocha and the institution of the region of Piauí, circa 1722, were political measures aimed at the land reform of a territory whose sesmarias were illegally donated to Casa da Torre, to Domingos Afonso Mafrense and the Society of Jesus. Some regal letters and licenses with legal content had been published prior to the foundation of Mocha with the expectation of distributing the vacant

(2) Outra (vila) de novo no citio do Arrayal do Ryo de S. Fran.co q' fica no meyo do caminho, q' sahe desta Cid.e p.a as minas gerays, onde continuam.te sucedem m.tas mortes, por falta de justiça, e por esta cuasa se impede em m.ta parte o commercio, receando os comboyeros passar por aquelles Certões, q' ficando já distantes desta Cid.e mais de duz.tas e oitenta legoas, o q' tudo se evitará creando-se Villa no d.o lugar (AHU_ACL_CU_BAHIA, Cx. 22, D. 2024).

(3) "Tem a Rib.ra do Assú, q' hé da Cap.nia do Rio Gr.de, além do numero e povoadores q' superabunda, p. a a erecção de Villa, hú admirável, e aprazível sitio, P. ${ }^{\mathrm{a}}$ se fundar, q' he o q' chamão do Curralinho sete legoas da Matriz, P. a pancada do Mar, onde chegão os carbos de Pern.co, por hú largo e fundo rio com todo o provim.to neçessr. ${ }^{\circ}$ p..$^{a}$ os mor.es, o q' só bastava, p. ${ }^{a}$ se conseguir o fim q'se pertende; q.to mais sendo fecundo de bom peixe p.la vizinhança q' tem com o Mar de huã legoa, e as terras circunvizinhas aptas, $p^{a}$ a produção das madiocas, de q' cá se faz a farinha; e abundantes de criações de gados, q' hé todo o necessr. ${ }^{\circ}$ nestas conquistas p. ${ }^{a}$ o passadio" (AHU_ACL_CU_PARAÍBA, Cx. 5, D. 428).

(4) For more information about the construction and urbanization of the captaincy of Piauí see ARRAES, Ezra. Plantar povoações do território: (re)construindo a urbanização da capitania do Piaú, 1697-1761. |Annals of the Museu Paulista, São Paulo, v. 24, n. 1, p. 257-298, Jan-|Apr. 2016 DOI: http://dx.doi.org/10.1590/1982-02672016v24n0110. 
sesmarias to those who denounced and required them. The Royal Charter of 20th January 1699 and the licenses of November 23rd 1700 were part of this agenda. The royal charter was directed at the Portuguese settlers, whilst the licence gave the religious missions a square league to support the Indian villagers. ${ }^{5}$

It is evident that the processes of territorial reform in Piauí began at the end of the seventeenth century, heating up with the creation of the town of Mocha, the "village-territory" in the sense of Massimo Cacciari (2010, p. 9). Nevertheless, its definitive construction would occur in 1758, when D. Joseph I made the captaincy official with an autonomous government. The autonomy was the result of the entourage led by judge Francisco Marcelino de Gouveia, which toured the whole captaincy, during the "great demarcations of Piauhy", in order to erect villages in the main settlements. Here, Piauí appears as a large laboratory of urbanistic testing, in which the definition of its administrative contours and the foundation of villages were guided by the perceptions of the agents of the Crown, acquired in situ.

Indeed, royal authorities selected two parishes to be converted into villages-Parnaguá and Surubim - due to their material "dignity" and financial indices obtained from the collection of tithes. The first, ... the parish is decently prepared with assistance from the Holy Sacrament and with destined income, and established for its perpetual existence..." (AHU_ACL_CU_PIAUÍ, Cx. 6, d. 395), would receive the title both for the "prosperity" of the inhabitants of its term, and its strategic position, "... because it is on the road that goes to the new lands, or newly discovered in the County of Villa Boa de Goyas and promises the place its existence, where they fetch the cattle, and those things necessary for the subsistence of the people that are in the said new lands..." (AHU_ACL_CU_PIAUÍ, Cx. 6, d. 395). As for Surubim, the materiality of the camp was the reason for its hierarchical elevation: "the settlement has thirty-seven hearths and the Church is also very decent" (AHU_ACL_CU_PIAUÍ, Cx. 6, D. 395). In geographical terms, the foundation of the two villages, one to the north and one to the south of the captaincy, would equate a triad capable of controlling and reordering areas formerly administered exclusively by Mocha, equitably distributing the respective terms, applying justice to the residents and dividing the captaincy into three parts of approximate dimensions. Marcelino de Gouveia's discourse demonstrated a clear idea of urbanizing, giving autonomy to the counties in order to reform the territory and fix the population of farms and smallholdings in settlements approved by the King. According to Araujo (2011, p. 7), this conferred on Piauí, a space of experiences and the adaptation of paradigms.

During the demarcations, Piauí became an image on a map designed by the military engineer and cartographer Henry Antonio Galuzzi. The cartographer was already in the village of Mocha in September 1759, before leaving for his inspection tour through streams, paths and carnaúba forests. Galuzzi asked the priest Ignacio Samartoni for astronomical data on the first satellite of Jupiter, in order to determine the longitudes required to prepare the map (ARAUJO, 2011, p. 7). In November of that year, Dr. Francisco Marcelino de George informed the Tome Joaquim Royal Court about the surveys carried out in parishes with the engineer, “... designed to make a precise and individual plan of the territory of the same [captaincy]...” (AHU_ACL_CU_PIAUÍ, Cx. 6, d. 395). Cartography would aid the method employed by the authorities in the construction of Piauí, both in political and geographical terms, or better, on paper, in a map drawn according to the measurement techniques of the age of enlightenment, as well as being a fundamental tool for the urban reform that was in progress. The judge established a connection between the drawing of the map and the imagined villages: "to add my opinion to his view of the places that should be erected, the terms of which and the people for whom the civil government is deemed most suitable..." (AHU_ACL_CU_PIAUÍ, Cx. 7, D. 435). ${ }^{6}$

After geometrically outlining the coast of Maranhão, Galuzzi turned to Piauí, where he traveled “... all that extreme spaciousness and undergoing innumerable difficulties, determining the direction

(5) The royal charter and the license are transcribed in the Annals of the National Library of Rio de Janeiro, vol. XXVIII, year 1906.

(6) “...p.a a vista delle interpor o meu parecer sobre os lugares que devem ser em V.as erigidos, termos q' devem ter, e pessoas q' p.a o governo civil dellas achace mais idoneas...”| 
of the paths and making repeated observations of latitude and longitude that was possible for me...". (AHU_ACL_CU_PIAUÍ, Cx. 7, d. 437). The Carta Geographica da Capitania do Piauhi, e partes adjacentes was the material and graphic result of the cartographic survey expedition. (Figure 2) The engineer was interested in drawing the territory's material and social specificities, punctuating the hierarchies of human settlements, the roads traversed and the indigenous ethnic groups that had not yet been reduced in religious missions or Indian villages. He also situated the orographic and hydrographic system of the region, basic content for the delimitation of terms and jurisdictions of future towns. The case of Piauí is emblematic, in particular concerning the spatial reorganization promoted by the enlightened policy of Sebastião José de Carvalho e Melo and his half-brother, Francisco Xavier de Mendonça Furtado.

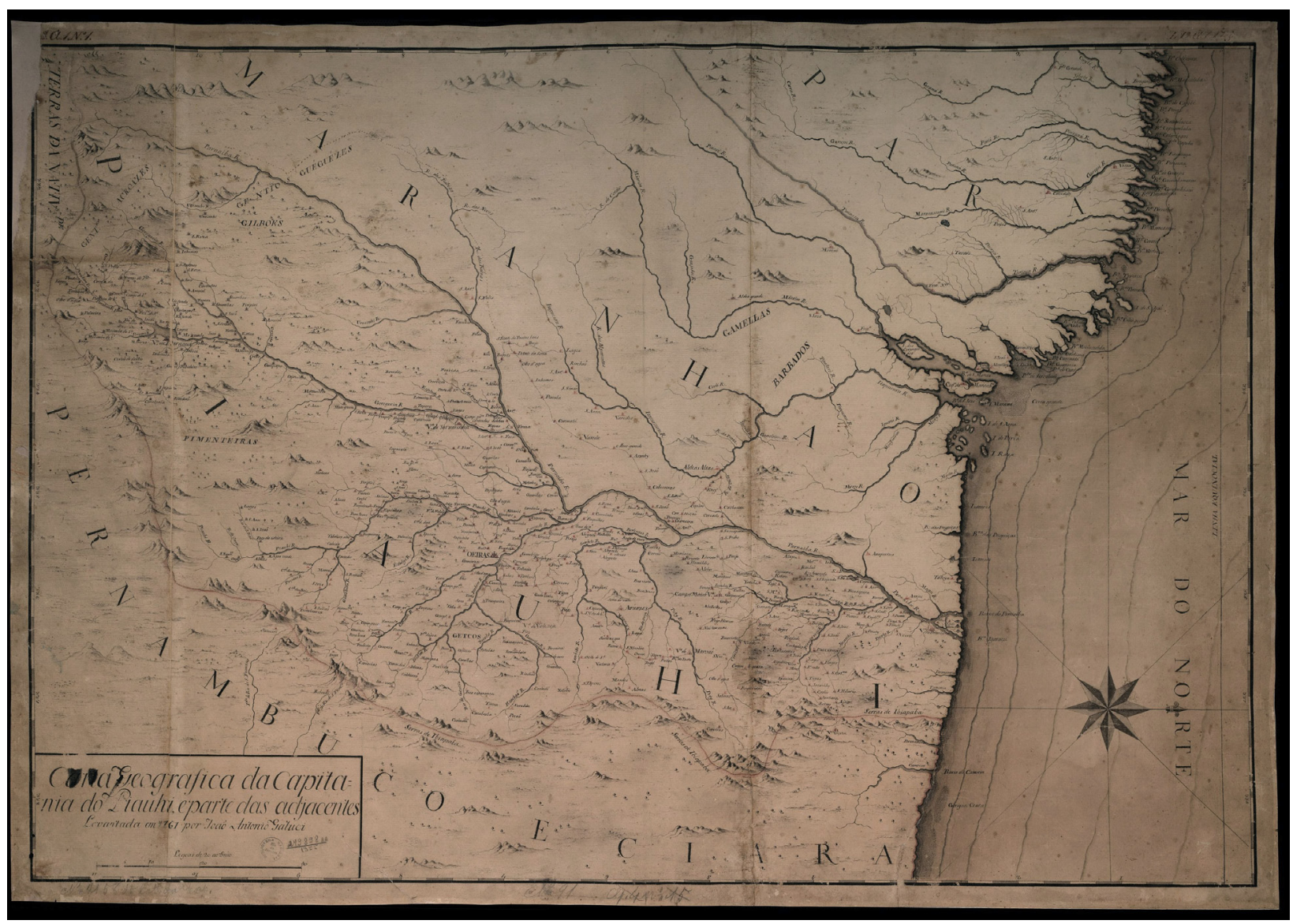

Figure 2 - GALUZZI, Henrique Antonio. Geographical Charter of the Captaincy of Piauhi, and part of the adjacent areas. Map available at www.bn.br. Accessed on: 30 mar. 2010.

The years subsequent to Pombal's ministry witnessed the emergence of other towns in the sertões and the institution of new counties with limits that did not correspond to the captaincies. Between 1789 and 1820, the Crown erected twenty-one villages in locations where the petitions justified the promotion (ARRAES, 2014, p. 72) (Figure 3). In this chronological interval, the Crown installed the village of Caxias das Aldeias Altas (formerly the julgado of the Aldeias Altas) located in the Maranhão captaincy on the banks of the Itapicuru River. The authorities had already alerted the Ultramarino Council regarding the physical and economic advances of the village in the mid-eighteenth century. In a letter to the Bishop of Pará, the Governor of Maranhão, Gonçalo Pereira Lobato e Sousa, was in favor of converting the julgado into a village, due to the population density that met the requirement, as well as for its strategic geographic position, because travelers and merchants arrived there from Piauí, minas de Goiás and all other parts of America (ANTT, mç. 601, no. 704). 


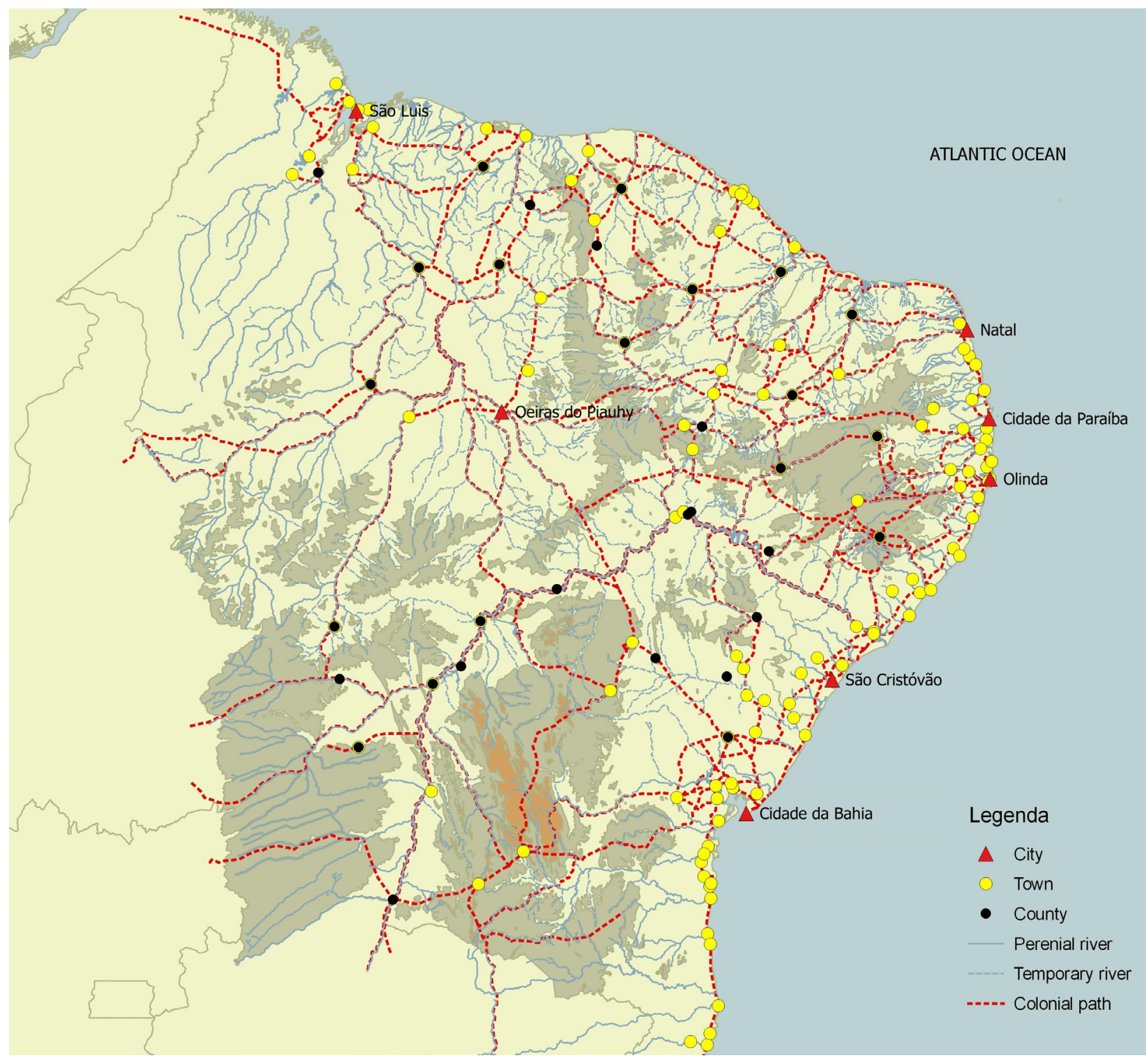

Figure 3 - Network of villages and captaincy towns in the North in 1820.| Author's design through georeferencing program (Quantum GIS) on cartographic basis of the Brazilian Institute of Geography and Statistics (IBGE). 
In 1767, the then governor of Maranhão, Joaquim de Melo and Póvoas, supported the creation of a village in Aldeias Altas "because it has enough people able to serve in the Chamber", besides being the trading port of the whole sertão (AHU_ACL_CU_MARANHÃO, Cx. 91, D. 7508). However, the Crown resisted granting the "dignity" of a village on the julgado. Its geopolitical strategies in the State of Grão-Pará and Maranhão privileged the definition of the borders of Portuguese America, the civilization of the Indians in urban spaces, as stipulated by the Indian Directory of 1757 and the territorial reform of the São José do Piauí captaincy. Years later, in 1796, another governor, D. Fernando Antonio de Noronha, requested the queen, D. Maria I, to elevate the status of Aldeias Altas. The request indicates extension of the julgado, the location of the township, the economic capacity of the territory, the modalities of trade and the number of inhabitants of the village (AHU_ACL_CU_MARANHÃO, Cx. 91, D. 7508). The qualifying aspects presented by royal officials would take effect in 1810 , when the title of village was granted in a new political conjuncture.

As far as the counties (or ouvidorias) were concerned, their creation was tardy in the sertões of the North, with the majority having arisen in the first two decades of the nineteenth century, a period in which D. João VI endeavored to reorganize the administration of justice by setting up the offices of outside judges and magistrates for certain villages. The first procuratorship - Bahia da parte do Sul ou Jacobina - arose in 1734 as a result of the fiscal and administrative requirements of the gold mined in the towns of Jacobina and Rio de Contas. The others, Sertão de Pernambuco (1810) with its "seat" in Flores do Pajeú; Crato (1816) and Rio São Francisco (1820) with its seat in the village of Barra, appeared in this context of judicial reform It should be noted that the "seat" villages of these procuratorships were located in the northern sertões, unlike the other county seats located on the coast: Bahia (1548), São Luís (1619), Olinda (1653), Paraíba (1688), São Cristóvão (1696), Saint Mary Magdalene (1709), Aquirás (1723), Cairú (1763), Porto Seguro (1763) and Natal (1818) (CUNHA, NUNES, 2016, p. 10).

\section{FINAL CONSIDERATIONS}

Now, the challenge is to chart the phenomena occurring in sertões in the North in thematic maps drawn in a GEO program. The result obtained in our doctoral research highlights duly occupied and transformed sertões during the colonial period. That way, landscapes are revealed in different narratives when the scales of approach vary. Thus, amalgamation can still be seen between the processes of urbanization and the construction of landscapes.

The cartography produced mainly in the eighteenth and nineteenth centuries and in the official documentation at the time, propitiated the design of a thematic map composed of six layers: the network of settlements - the networks of smallholdings and farms - sugar cane mills - salt mines and paths (figure 4). On the "network of settlements" layer, 530 villages were located in an attributes table that favors the length of duration. The fields established are based on various hierarchical levels: toponymy; captaincy; arrival; registry; passage; religious mission; chapel; curacy; Crown parish; diocesan vicar; Indian parish; Indian place; village; town; county seat; magistrates' seat; the seat of the diocese and Archdiocese. Whereas the attribute table of the layer "network of smallholdings and farms" displays some 610 elements distributed mostly in the captaincies of Piauí, Pernambuco, Bahia and Maranhão. In fact, the purpose of the thematic maps is to re-present the sertões outside of the usual scenario, more dynamic and related to the social experiences lived in a rich and complex system of settlements. From this perspective, pensar con los ojos means to shift the obscurum to the stage of protagonist actions. 


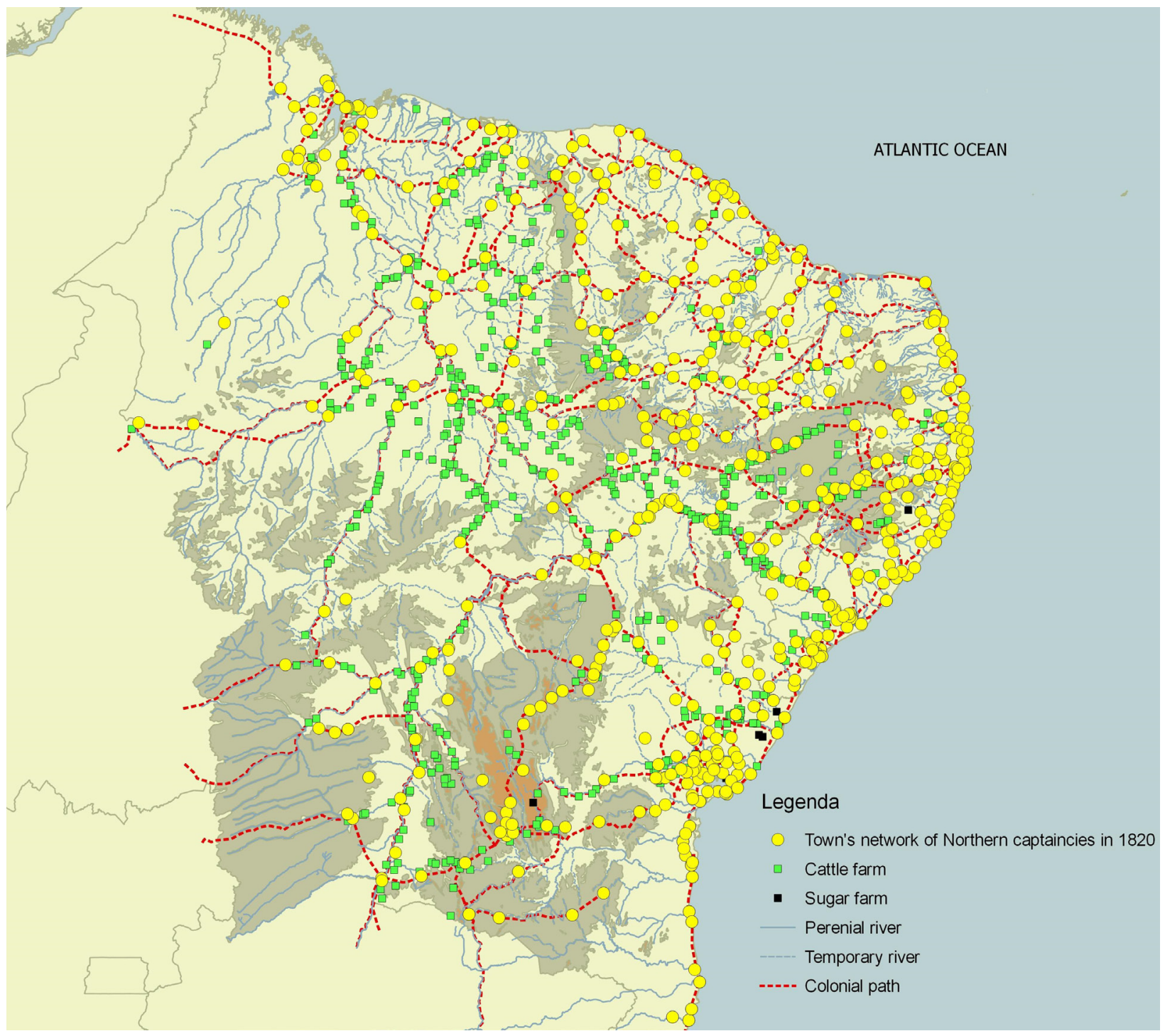

Figure 4 - Thematic maps showing the state of settlement and the network of settlements in the capitancies of the North at the end of the colonial period. Map produced by the author through a georeferencing program (Quantum GIS) on the cartographic basis of the Brazilian Institute of Geography and Statistics (IBGE). 


\section{ACKNOWLEDGEMENTS}

I am grateful to the Foundation for São Paulo Research Foundation (FAPESP) for the scholarship granted (process $\mathrm{n}^{\circ} 2013$ / 04404-9) that made the doctorate research possible, whose partial results are presented briefly in this article. I am grateful to Prof. Beatrice p. Siqueira Bueno for her competent and delicate guidance on the empirical and epistemological doctoral paths. I cannot forget the valuable contribution made by the anonymous reviewer regarding the final configuration of the article. Their comments and suggestions have been fundamental for both this text and my future research.

\section{BIBLIOGRAPHIC REFERENCE}

ANDRADE, Amélia Aguiar. A construção medieval do território. Lisboa: Livros Horizontes, 2001.

ARAUJO, Renata Malcher de. Desenhar no papel e no terreno: cartografia e urbanismo na Amazóna e Mato Grosso no século XVIII. In: OLIVEIRA, Francisco Roque; VARGAS, Héctor Mendonza (coord.). Mapas da metade do mundo. A cartografia e a construção territorial dos espaços americanos: séculos XVI a XIX. Lisboa: Centro de Estudos Geográficos - UL, 2010.

ARAUJO, Renata. O Piauí e sua cartografia. Anais do IV Simpósio LusoBrasileiro de cartografia histórica. Porto, 2011.

ARRAES, Esdras. "Curral de reses, curral de almas: introdução à urbanização dos "certoens" das capitanias do Norte". Revista do Instituto de Estudos Brasileiros, n 58, p. 51-77, jun. 2014. DOI: http://dx.doi. org/10.11606/issn.2316-901X.v0i58p51-77

ARRAES, Esdras. "Plantar povoações do território: (re)construindo a urbanização da capitania do Piauí, 1697-1761” Anais do Museu Paulista, São Paulo, v. 24, n. 1, p. 257-298, jan.-abr., 2016. DOI: http://dx.doi. org/10.1590/1982-02672016v24n0110

BAYÓN, Damián. Pensar con los ojos. 2 ed. Cidade do México: Fondo de Cultura Económica, S.A., 1993. BLUTEAU, Raphael. Vocabulario Portuguez \& latino: aulico, anaomico, architectonico...Coimbra: Collegio das Artes da Companhia de Jesu, 1712-1728. Vol. 7. Disponível em http://www.bbm.usp.br. Acesso em 6 abr. 2017.

BUENO, Beatriz P. Siqueira. "O Brasil-Colônia: em que medida mais urbano do que pertence à primeira vista". Actas Primer Congreso Iberoamericano de Historia Urbana. Ciudades em el tiempo: infraestructura, territorios, patrimonios, Santiago de Chile, mesa n. 21, p. 825-834, 2016.

CACCIARI, Massimo. A cidade. São Paulo: Gustavo Gili, 2010.

CASTRO, Silvio. A carta de Pero Vaz de Caminha. Porto Alegre: L\&PM, 2015.

CERTEAU, Michel de. A invenção do cotidiano: artes de fazer. 19 ed. Petrópolis: Vozes, 2012.

DUBBINI, Renzo. Geography of the gaze: urban and rural vision in early modern Europe. Chicago: University of Chicago Press, 2002.

FREIRE, Felisbelo. História de Sergipe. 2 ed. Petrópolis: Vozes, 1977.

HARLEY, J. B. La nueva naturaleza de los mapas. Ensayos sobre la historia de la cartografia. México D.F.: Fondo de Cultura Económica, 2005.

JACKSON, J. B. Discovering the vernacular landscape. New Heaven and London: Yale University Press, 1984.

LAGO, Antonio Bernardino Pereira do. Estatística Historica-Geografica da Provincia do Maranhão oferecida ao Soberano Congresso das Cortes Geraes, Extraordinarias, e Constituintes da Monarchia Portugueza. Lisboa: Typ. da Academia Real das Sciencias, 1822.

LEPETIT, Bernard. Por uma nova história urbana. São Paulo: Edusp, 2001.

MARTINHO DE NANTES, padre, O.F.M. Cap. Relação de uma missão no Rio São Francisco: relação sucinta e sincera da missão do padre Martinho de Nantes pregador capuchinho, missionário apostólico no 
Brasil entre os índios chamados cariris. 2 ed. São Paulo: Ed. Nacional, 1979.

MILLER, Daniel. Trecos, troços e coisas: estudos antropológicos sobre a cultura material. Rio de Janeiro: Zahar, 2013.

OSORIO, José Ramón Menéndez de Luarca y Navia. La construcción del territorio: mapa histórico del Noroeste de la Península Ibérica. Madrid: Lundweg Editores, 2000.

PUNTONI, Pedro. A guerra dos bárbaros: povos indígenas e a colonização dos sertões Nordeste do Brasil, 1650-1720. São Paulo: Hucitec; Edusp; Fapesp, 2002.

SILVA, Antonio de Moraes. Diccionario de Lingua Portugueza - recompilado dos impressos ate agora, e nesta segunda edição novamente emendado e muito acrescentado. Lisboa: Typographia Lacerdina, 1813. Disponível em www.bbm.usp.br. Acesso em 6 abr. 2017.

SOUSA, Gabriel Soares de. Tratado descritivo do Brasil em 1587. São Paulo: Cia. Editora Nacional; Edusp, 1971.

STUDART FILHO, Carlos. Vias de comunicação do Ceará colonial. Revista do Instituto do Ceará. Tomo LI. Fortaleza, 1937.

\section{PRIMARY WRITTEN SOURCES}

CONSULTA do Conselho Ultramarino ao rei D. Pedro II, sobre o caminho que se descobriu e se abriu do Maranhão a Bahia. Arquivo Histórico Ultramarino_Administração Central_Conselho Ultramarino_Maranhão, Cx. 9, D. 906.

CONSULTA do Conselho Ultramarino ao rei D. Pedro II sobre o novo caminho que se descobriu no Maranhão e cartas do governador geral do Brasil e do padre Jacob Cloceo. Arquivo Histórico Ultramarino_Administração Central_Conselho Ultramarino_Maranhão, Cx. 9, D. 957.

DESPACHO do Conselho Ultramarino referente a provisão de D. João de Lencastro sobre se erigiram em vilas os lugares chamados de Itapicuru e Inhampube. Arquivo Histórico Ultramarino_Administração Central_Conselho Ultramarino_Sergipe, Cx. 03, D. 22.

PARECER do procurador da Coroa sobre a ereção de uma vila entre o Rio Real e Itapicuru. Anexo carta do ouvidor da comarca da Bahia. Arquivo Histórico Ultramarino_Administração Central_Conselho Ultramarino_Bahia, Cx. 22, D. 2024.

OFÍCIO do desembargador, Francisco Marcelino de Gouveia, ao secretário de estado da Marinha e Ultramar, Tomé Joaquim da Costa Corte Real, sobre o plano que efectuou do território do Piauí e da divisão do mesmo em duas ouvidorias; remetendo uma lista de pessoas que poderão trabalhar no governo civil da capitania. Arquivo Histórico Ultramarino_Administração Central_Conselho Ultramarino_Piauí, Cx. 6, D. 395.

OFÍCIO do desembargador, Francisco Marcelino de Gouveia, a Franciso Xavier de Mendonça Furtado, sobre o cumprimento da execução de um plano geral da capitania, no que se refere a uma boa administração da justiça e arrematação dos dízimos reais. Arquivo Histórico Ultramarino_Administração Central_Conselho Ultramarino_Piauí, Cx. 7, D. 435.

OFÍCIO do engenheiro, Henrique António Gallucio, a Francisco Xavier de Mendonça Furtado, sobre as configurações geométricas que efetuou em toda a costa marítima, desde Pará ao Maranhão e capitania do Piauí, para a elaboração de cartas geográficas da capitania, enviando um requerimento a solicitar a sua nomeação para o cargo de sargento-mor engenheiro, com soldo dobrado. Arquivo Histórico Ultramarino_Administração Central_Conselho Ultramarino_Piauí, Cx. 7, D. 437.

CARTA do ouvidor geral da Paraíba, Manuel da Fonseca e Silva, ao rei (D. João V), sobre a correição que vai fazer na ribeira de Piancó e ser conveniente fundar vila no sítio da matriz de Nossa Senhora do Bom Sucesso bem como na ribeira do Apodi e na do Açu, todas da jurisdição da Paraíba, no tocante à justiça. Arquivo Histórico Ultramarino_Administração Central_Conselho Ultramarino_Paraíba, Cx. 5, D. 428.

CARTA do governador e capitão-general do Estado do Maranhão, D. Fernando Antonio de Noronha, para a rainha D. Maria I, a solicitar a elevação do jugado de Aldeias Altas à dignidade de vila. Arquivo Histórico Ultramarino_Administração Central_Conselho Ultramarino_Maranhão, Cx. 90, D. 7508.

CARTA de Gonçalo Periera Lobato e Sousa ao bispo do Maranhão D. frei Miguel de Bulhões. ANTT. Mi- 
nistério do Reino, mç. 601, Cx. 704, n. 38.

CARTA de Wenceslau Pereira da Silva a Sebastião Joze de Carvalho e Mello sobre as minas de salitre na capitania da Bahia. ANTT. Correspondência recebida do Brasil (Baía). Ministério do Reino, mç. 599, n. 41.

CARTA do Provedor do regimento; e guarda mor das minas do Rio das Contas, Manuel Dias Mascarenhas, para o Conselheiro Intendente Geral da Baia, Wenceslau Pereira da Silva. ANTT. Correspondência recebida do Brasil (Bahia). Ministério do Reino, mç. 599, n. 47.

ROTEIRO do caminho para Pojuca, passado por Urubá, capitania de Pernambuco. 1738. IEB/USP-COL. ML, 72.60. 